\title{
Commentary
}

\section{Going toward Resilience? Town Planning, Peri-Urban Landscapes, and the Expansion of Athens, Greece}

\author{
Samaneh Sadat Nickayin ${ }^{1}$, Antonio Tomao ${ }^{2, *}{ }^{\circledR}$, Giovanni Quaranta ${ }^{3}{ }^{(0)}$, Luca Salvati ${ }^{4}$ \\ and Antonio Gimenez Morera ${ }^{5}$ \\ 1 Planning and Design Faculty, Agricultural University of Iceland, Hvanneyri, 311 Borgarbyggð, Iceland; \\ samaneh@lbhi.is \\ 2 Department for Innovation in Biological, Agro-Food and Forest Systems (DIBAF), University of Tuscia, \\ Via S. Camillo de Lellis, s.n.c., I-01100 Viterbo, Italy \\ 3 Department of Mathematics, Computer Science and Economics Department, University of Basilicata, \\ Viale dell'Ateneo Lucano, I-85100 Potenza, Italy; giovanni.quaranta@unibas.it \\ 4 Department of Economics and Law, University of Macerata, Via Armaroli 43, I-62100 Macerata, Italy; \\ luca.salvati@unimc.it \\ 5 Departamento de Economia y Ciencias Sociales, Universitat Politècnica de València, Cami de Vera s/n, \\ ES-46022 València, Spain; angimo1@doctor.upv.es \\ * Correspondence: antonio.tomao@unitus.it; Tel.: +39-076-135-7407
}

Received: 23 November 2020; Accepted: 12 December 2020; Published: 15 December 2020

\begin{abstract}
The long-term expansion and the evolution of town planning of a contemporary European metropolis (Athens, Greece) has been analysed in this study in order to evaluate how sustainable urban growth has been taken into account in sequential strategic master plans. During the last decades, the mostly unplanned urban growth and massive housing construction have favoured a slow evolution towards a less compact and mono-centric spatial asset, typical of several Mediterranean cities. Despite efforts to guide urban growth, a series of structural challenges have remained: (i) a gap between planning and implementation; (ii) a gap between spatial planning and socio-economic planning; (iii) a relevant pressure on natural environment; (iv) a lack of participatory planning. In order to face these problems, current strategies for the city of Athens try to foster city resilience providing guidelines for more sustainable management of the built and natural landscape. In particular, the Resilience Strategy for 2030 proposes a list of actions to improve the well-being of citizens and to increase sustainability at the urban and territorial levels. A major role was given to the enhancement of the environmental quality of the metropolitan area and to the involvement of inhabitants in the various phases of decision-making.
\end{abstract}

Keywords: strategic master plan; urban expansion; demographic pressure; green belt; green infrastructure; Greece

\section{Introduction}

Urban expansion, accompanied by negative externalities of agglomeration and adverse impact on natural environment [1-3], generates unprecedented pressures and challenges in peri-urban landscapes [4]. In the last decades, a wide debate has been developed among stakeholders and practitioners on how planning strategies (and the related settlement morphology) may support the intrinsic transition toward urban sustainability more effectively [5,6]. In this context, earlier studies argued that mono-centric and compact cities show lower $\mathrm{CO}_{2}$ emissions derived from household travel and residential energy consumption [7,8] and support a better quality of life [9] than dispersed and sprawled urban areas. Furthermore, a compact urban form theoretically preserves more functional 
spatial relationships among land uses distributed along the metropolitan gradient if compared with more dispersed and polycentric structures $[10,11]$. From the point of view of land consumption, mono-centric cities will probably facilitate the implementation of strategies for soil conservation [12]. Indeed, protecting natural relict areas and contrasting settlement sprawl may be more effective in mono-centric urban areas, if planned in the context of integrated protection of agro-forest areas and environmental corridors, basically known within the general notion of 'green infrastructure' $[13,14]$. The creation of green belts around consolidated cities tends to crystallize the spatial distribution of land use according to the Von Thunen model, creating, e.g., a polarization between agriculture and forestry that intrinsically leads to simplified landscapes [15]. This context would be suboptimal for measures preserving linear elements of natural landscapes, e.g., through a strategy that valorises green infrastructures [16]. However, benefits related to the preservation of pristine agricultural, forest, pasture and other valuable (green) land uses, should be increasingly balanced with issues concerning environmental quality and local acceptance of a more compact form of urban living $[17,18]$. For instance, although a compact city form can reduce the distance (an therefore the cost) to reach workplace [19], polycentric cities may reduce problems associated with traffic congestion and other agglomeration diseconomies [4]. Furthermore, lower-sized, scattered, polycentric urban forms are generally associated with better air quality and a fewer emission of several pollutants $\left(\mathrm{PM}_{2.5}, \mathrm{PM}_{10}\right.$, $\left.\mathrm{CO}, \mathrm{SO}_{2}, \mathrm{NO}_{2}, \mathrm{O}_{3}\right)[20,21]$. These partially controversial evidences about pros and cons of compact and polycentric urban development make rather challenging to give universal recommendations for sustainable planning. Indeed, planning choices can be different based on the history of urban growth and socio-economic and territorial context.

Athens, the Greek capital, is a Mediterranean city where suburbanization-driven settlement scattering and polycentric development have progressively altered the typical mono-centric spatial organization of the metropolitan region at large [22]. Investigating the long-term expansion of Athens in light of the planning antinomy between mono-centric and polycentric settlement models [23], can reveal the true essence of such phenomenon in the Mediterranean region, being intimately linked with the expansion of new intermediate density settlements and the subsequent self-containment of new built-up areas [24]. Urban sprawl-intended as 'a pattern of urban and metropolitan growth reflecting low-density, automobile-dependent, exclusionary new development on the fringe of settled areas often surrounding a deteriorating city' -is a relatively recent socioeconomic process in Athens. However, sprawl has (more or less) rapidly determined a transition from a traditional urban-rural polarized landscape to more diffused urban assets spreading over the available (pristine) land, sacrificing agricultural and forested areas [25]. Such rapid changes in metropolitan structures have arisen major concerns for long-term sustainability in Athens, as well as in many other Mediterranean cities [26]. Indeed, as the population across the Mediterranean basin has approximately stabilized on constant values, the necessity of converting more natural land to urban use is not completely justified [27]. With the environmental and economic challenges that Southern European countries are facing, switching from compact growth to sprawl seems to be a sub-optimal choice [28], especially in light of increased urban competitiveness amongst world regions [29]. The negative impact of sprawl on environments and societies sheds light on urban policies for controlling the phenomenon in such a delicate moment of urban and economic crisis [30-34]. In this context, the Rockefeller Foundation developed a specific Resilience Strategy for the city of Athens, as a part of the "100 Resilient Cities" (100RC) initiative, with the aim to respond to the current trends of urbanization, globalization and climate change. The Athens Resilience Strategy proposes a series of actions which can help the city to move towards an improved urban resilience, defined as the "capacity of individuals, institutions, businesses and systems within a city to adapt, survive and thrive no matter what kind of chronic stresses and acute shocks they experience" [35]. 
Bearing in mind these considerations, the present commentary aims at analysing the long-term expansion of a contemporary European metropolis (Greece, Athens) from a specific disciplinary perspective, i.e., the evolution of town planning, defining how a sustainable urban growth has been taken into account in sequential measures of the strategic master plans enforced in law [36]. With this perspective in mind, the work debates on more specific needs that should be addressed by local spatial development strategies to effectively ensure sustainability goals expressed in the Athens Resilience strategy for 2030 [35].

Following this introduction, Section 2 reviews how earlier plans at different spatial, operational, and administrative scales have designed Athens expansion since World War II. Section 3 discusses the sustainability development of such plans in the light of Athens Resilience Strategy for 2030, outlining future trends for Athens and generalizing our results to other socioeconomic contexts in Southern Europe.

\section{Town Planning and Athens' Expansion}

The historical development of Athens, considered within the wider urban network of the country, has been influenced by the predominant role of the capital city since the 1950s at the expense of all other Greek cities [37]. Attica, and its main city Athens, was the main engine of territorial development for at least one century in Greece [38]; the spatial imbalance between Athens and the rest of the country (possibly excluding only Thessaloniki, the second city in the country) has continued uninterrupted until the beginning of the 1980s $[39,40]$. In the modern globalized economy, Athens is the only metropolitan centre in Greece with a well-recognized international role [41]. Most of the academic, administrative, cultural, research and sports activities are concentrated here [41]. Furthermore, more than one-third of the Greek population (nearly 4 million inhabitants, [42]) is living in the Attica region, which acts as an undiscussed hub for the Greek economy [43-45].

Like a typically Mediterranean city, the Athens' expansion was characteristic of a city that followed an undersigned way, based on small, self-financed property development, with limited public expenditure for urban infrastructure [25,29,46-48]. Until recently, the most relevant planning

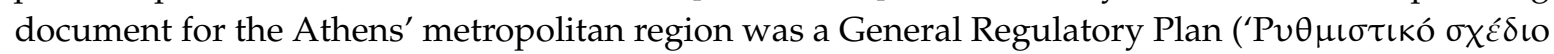

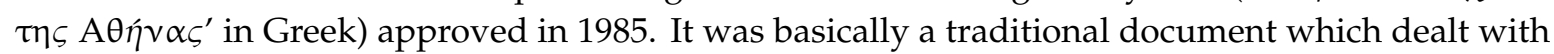
land-use regulation, zoning, and spatial location of the main infrastructures in the area [25]. In the following we reviewed the main planning efforts for the territory of Athens since the end of World War II, focusing on the socioeconomic drivers supposed to influence planning choices [49].

\subsection{Planning Athens from World War II to 1980s}

After World war II, Athens experienced the first wave of urban expansion, mainly driven by a population growth which doubled in 30 years from 1,378,000 (1951) to 3,038,000 inhabitants (1981) [25]. Most of the newcomers were internal migrants in search of employment opportunities and settled in the western part of the city, in areas near industrial plants and some undefined land uses [50-52]. During this period, several attempts of urban plans, studies, and proposals were elaborated, including two seminal plans by Doxiadis dated 1945 and 1960. Even if those plans were not put into practice, they can be considered the forerunner of the present ones and were intrinsically linked with the extensive contribution of other urban planners and scholar, such as Biris [53]. Indeed, in the Doxiadis Plan of 1945, the main road axes that have been implemented later as the Attiki Odos road which links Athens with Thessaloniki, and the national road linking Athens with Patras, were clearly designed. These main roads have definitely influenced the subsequent urban expansion since crossed agricultural areas, after the construction of the highway, became residential. The Doxiadis Plan for Athens-Oikoumenopoli proposed in 1960 prefigured a new centre (Tatoi) in the same peripheral area. Being a particularly well organized proposal, it was preceded four years earlier by a specific work of the topographer Siokos, who had formulated a similar proposal for a new development centre on the right bank of the river Kifisos, the "city of public employees" for Athens. It is worth mentioning 
that, more than 50 years later, most of the dwellings in the Thrakomakedonos Olimpic Village-few kilometers northside-were sold to civil servants, creating in nuce the neighbourhood envisaged by Siokos. The Doxiadis plans also included the possibility of urban expansion toward the sea for second homes.

Another plan proposed for the City of Athens was the "Urban Traffic and Mobility Plan" of 1964, drafted by Wilbur Smith and Association. Smith's proposal was at least incomplete regarding transport planning, especially about the way they promoted the use of private cars. It should also be noted that at the same time Smith's study of the Traffic Plan and Mobility Plan for the City of Helsinki proposed the demolition of the tram network and its replacement by buses and a metro line. A proposal that Finnish town planners had rejected. In Athens, tramways have been demolished since 1955. Therefore, the subsequent plans had to adapt to the road system already built, in which the lines proposed by the 1985 Master Plan were compared with the Smith plan (Figure 1).

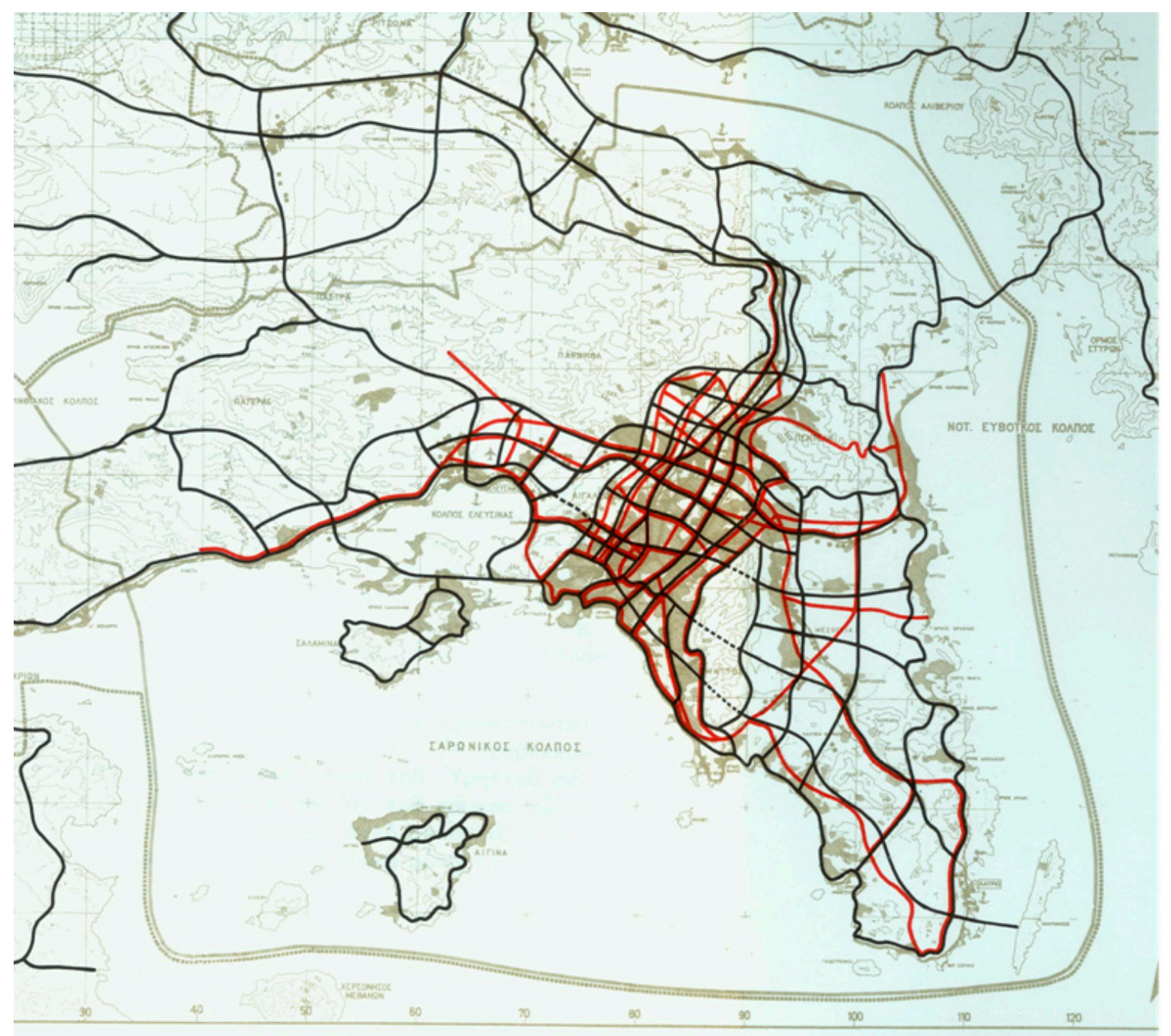

Figure 1. The road networks in the 1985 plan, black, and in the Smith plan, red (Source: redrawn by an original map provided by Technical Construction Chamber of Greece). 
Despite an increasing attention for urban planning, the 1950s and 1960s were characterized by widespread informal housing (Figure 2). This uncontrolled urban expansion caused a compaction and densification of urban cores in the 1950s, and a more dispersed growth along the seacoast and on Athens' fringe (1960s). The classification of peripheral land as "out of plan" areas until the 1985 plan stimulated settlement deregulation. These neighbourhoods, often without implementation plans for roads and services, resulted from direct conversion of farmland and/or spontaneous vegetation to urban uses [54]. Most of them were of interest to the implementation plans issued by the technical offices of the individual municipalities and specifically designed to grant building allowances [49]. In general, building permits reported a low volume in order to avoid large heights, with the final aim at classifying these newly built areas as 'rural' to escape more strict regulations enforced in law for strictly urban areas [50]. However, in the period of dictatorship (1967-1974), the laws (inspired by populist politics) allowed multilevel buildings in the "out of plan" territories [55]. Moreover, degraded living conditions in downtown Athens and Piraeus witnessed the first demographic displacements toward suburban locations, seeking for better environmental quality and less pollution [56]. In the absence of an approved plan, the net result was land speculation and a proliferation of new built-up areas along the fringe. The sprawl resulted in the constitution of new "centres" in rural areas [57], including Maroussi (the headquarters of Greek public telecommunications, equipped with metro line), Haidari (a military area), Menidi (a public land in Amygdaleza) and Elliniko (a former airport). Following a national law (395/1968), already in the 1980s, small and medium-sized "shopping centres" were built along the road axes around the more expensive suburban areas, moving buyers from the urban centre to the periphery.

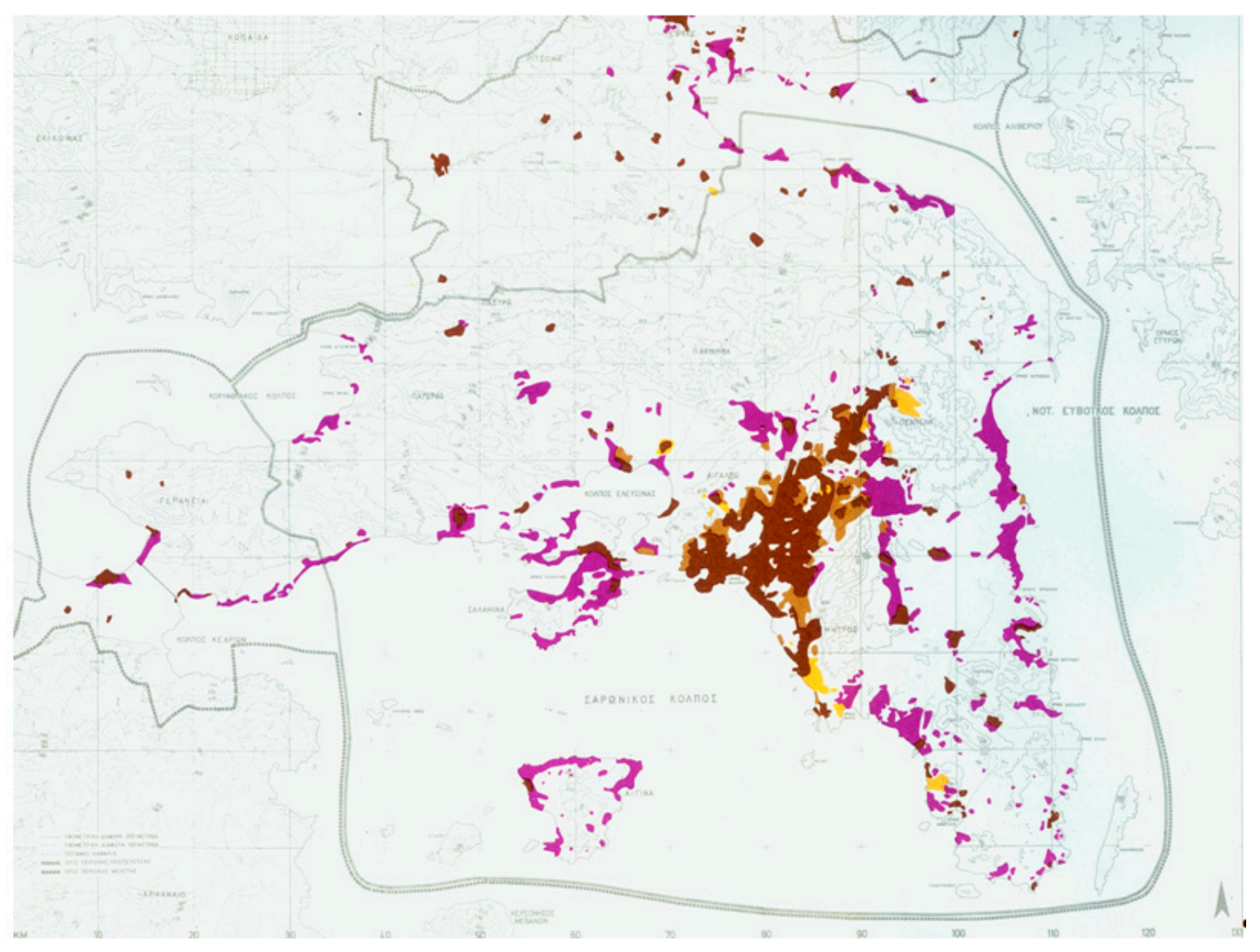

Figure 2. Informal housing by decades in Attica (1950s: dark brown; 1970s: purple; informal areas later included in the 1985 regional plan: light brown; newly built areas according to the 1985 regional plan: yellow (Source: redrawn by an original map provided by Technical Construction Chamber of Greece). 


\subsection{The 1985 Regulatory Plan and the Intrinsic Settlement Dispersion of the 1990s}

After years of continuous elaboration of regulatory plans, based on a proposal by Vasileiadis in 1966, the Regulatory Plan (RP) of Athens elaborated by the Doxiadis Technical Study was approved in 1985 by the Ministry of Environment, Planning and Public Works ( $П \mathrm{EXX} \Omega \mathrm{E}$ ). The approval of the plan, by law no. 1515/85, made it possible to implement the planning in Athens and other neighbouring cities for the first time [25]. This was an important step forward for the actual management of the area because in the previous decades no regulatory plans were approved and made operational. The plan included the entire Attica basin (forming the largest part of Athens' conurbation, well known as the Greater Athens' area), as well as all the peri-urban areas which had not yet been considered in earlier urban development regulations [58-60].

One of the main actions envisaged in the 1985 plan consisted of the division of Attica in centres, i.e., the so-called "suburbs". The choice was to deconcentrate the Attica basin thus favouring an urban structure which facilitates citizens' pedestrian access to basic functions. The process would result in a de-centralization of functions not related to Attica alone, while the "extended centre" would retain the role of a directional centre. The extended centre of Athens was considered autonomous and organized into five subdivisions: Lekanopedio (Attika basin) and Salamina Island, which refer to Athens City Hall as the centre; West Attica with Megara centre; North Attica with an enlarged centre in the rural municipality of Kapandriti, along the Athens-Thessaloniki road; Eastern Attica with the centre of Lavrio and Attica island with a centre at Egina, likely the most populated island in the Argosaronikos Gulf close to Piraeus.

While providing for the expansion of existing settlements, the RP introduced specific measures protecting open spaces and green areas. Indeed, the Regulatory Plan of 1985 paid a particular emphasis on the protection of the environment and rural territory by establishing a first network of 'formally' protected areas (Figure 3). Theoretically, the Plan was aimed at creating a sort of green belt around the Greater Athens' area, reconnecting the biodiversity-rich mountainous territory West, North and East of the city (formed by a continuous chain of four mountains: Egaleo/Poikilo, Parnitha, Pendeli, and Imitos). However, the natural reserves that exist today in Attica were not completely considered in this plan, fundamentally prepared in the 1980s before the 'building boom'. An example is Penteli Mount, a natural site close to Athens where urban expansion was approved (or, at least, tolerated) also on burned areas. A similar status has characterized Imitos Mount still now, with restricted protected sites (e.g., labelled as 'natural heritages' or 'biophysical refugees' in Greek) and the large majority of the natural area being substantially unprotected and continuously experiencing environmental threats (e.g., wildfires), landscape fragmentation (e.g., construction of the peripheral ring road) and land speculation, at least up to the early 2000s. Particular attention in the new plan was dedicated to the archaeological areas and cultural heritage. Specific hotspots were finally identified in mixed areas with important archaeological reliefs requiring an improved level of protection. 


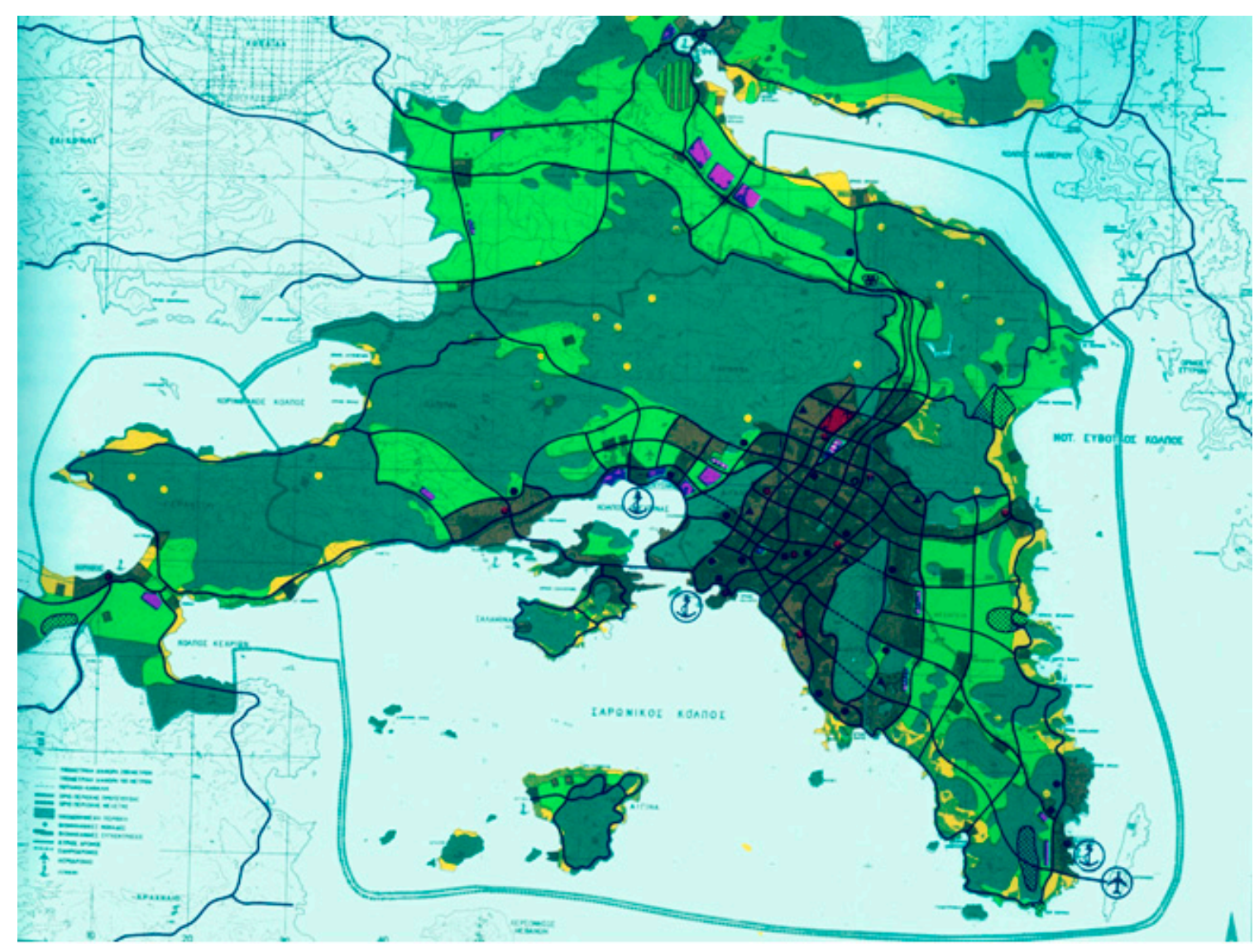

Figure 3. Map with selected land use classes: dark green: natural reserves, light green: crops; yellow: pastures, wetlands and other non-forest natural areas; violet: industrial zones (Source: redrawn by an original map provided by Technical Construction Chamber of Greece).

Other relevant actions envisaged by the RP were the location of the new Athens Airport in the Spata area (Messoghia plain) and the progressive abandonment of the old airport in Ellinikò, South of Athens. This decision was part of a new axis for public and private transport, which also included changes related to the development of the ports (as in the case of Faliro), as well as a series of proposals for road extension, construction of new sport installations and industrial development (Figure 4).

The location of the new Athens Airport in Messoghia agricultural district had a relevant impact on the local territory both from the point of view of noise and marine pollution (Figure 5). The choice of such area was criticized in the subsequent years, mainly because of great commercial land-related interests and the firms that would win the road construction contract. Companies linked to German interests built both the airport and Attiki Odos, the connecting road to the city, and the national roads. 


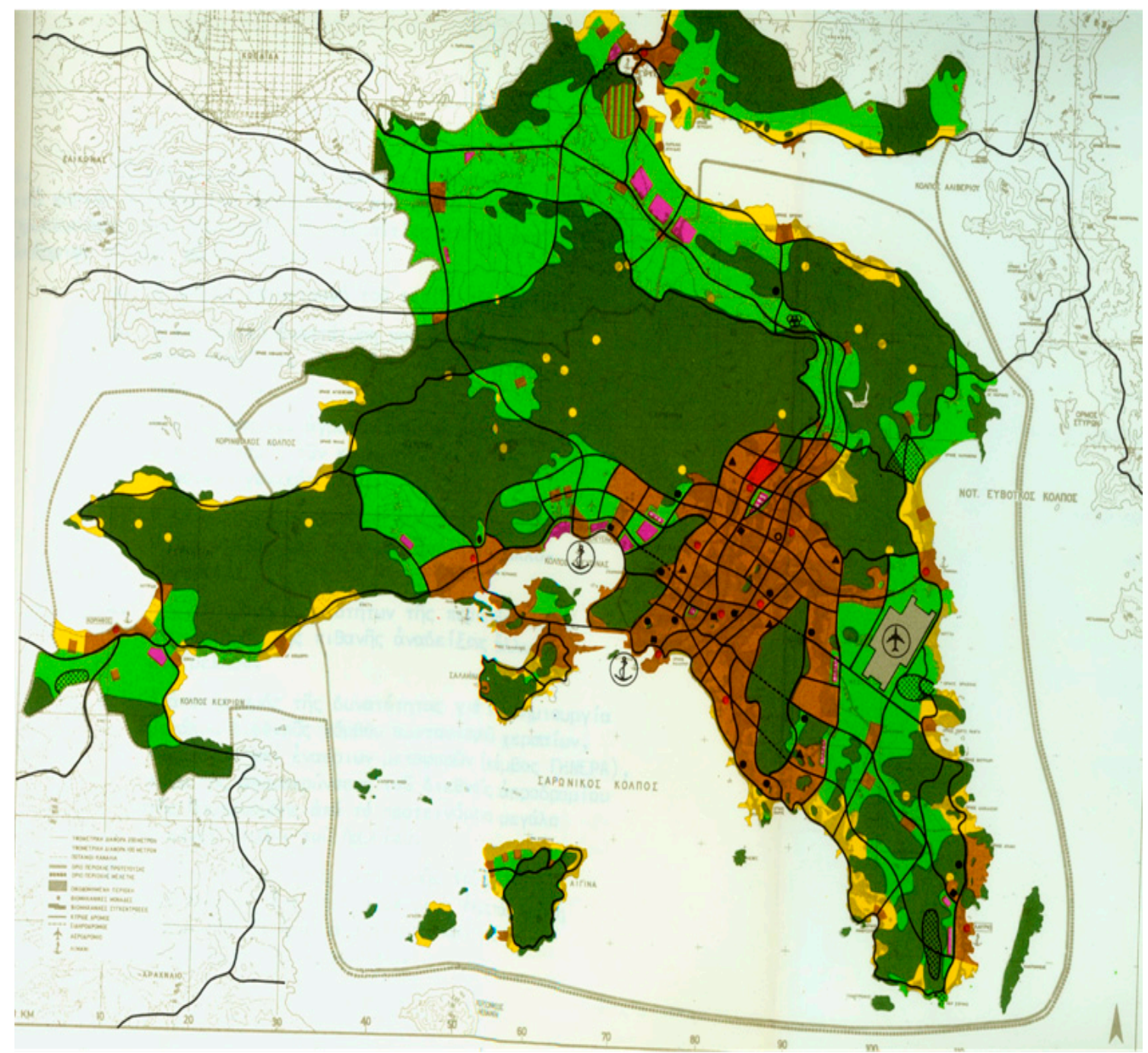

Figure 4. A comprehensive map of land-use destinations in Attica with the new international airport. Residential settlements are illustrated in brown, yellow means "holiday homes", violet depicts the industrial areas, red includes the national directional centres. Natural reserves and cropland were illustrated respectively in dark green and light green (Source: redrawn by an original map provided by Technical Construction Chamber of Greece).

After the Doxiadis plan of 1985, the first major reform was established in the Law 2052/1992 (Measures to combat smog and urban adaptation). The law proposed to abolish the dispersion of local centres at the municipal level-adopted by 1515/85 based on the idea to provide pedestrian access to the main functions to the citizen - and therefore to create four main centres with the aim at decongesting Athens and Piraeus agglomerations. The new centres were called as "secondary centres for the territorial division of the Attica basin". This decongestion strategy was already present in the law AN395/68 (law for maximum heights, percentage of edification on soil, free-standing silhouette system from construction lines). The consequence of this law was an intense construction in urban areas, meeting the demand of entrepreneurs to reduce the decline of housing growth and construction activity downtown, due to the unacceptable life quality. 


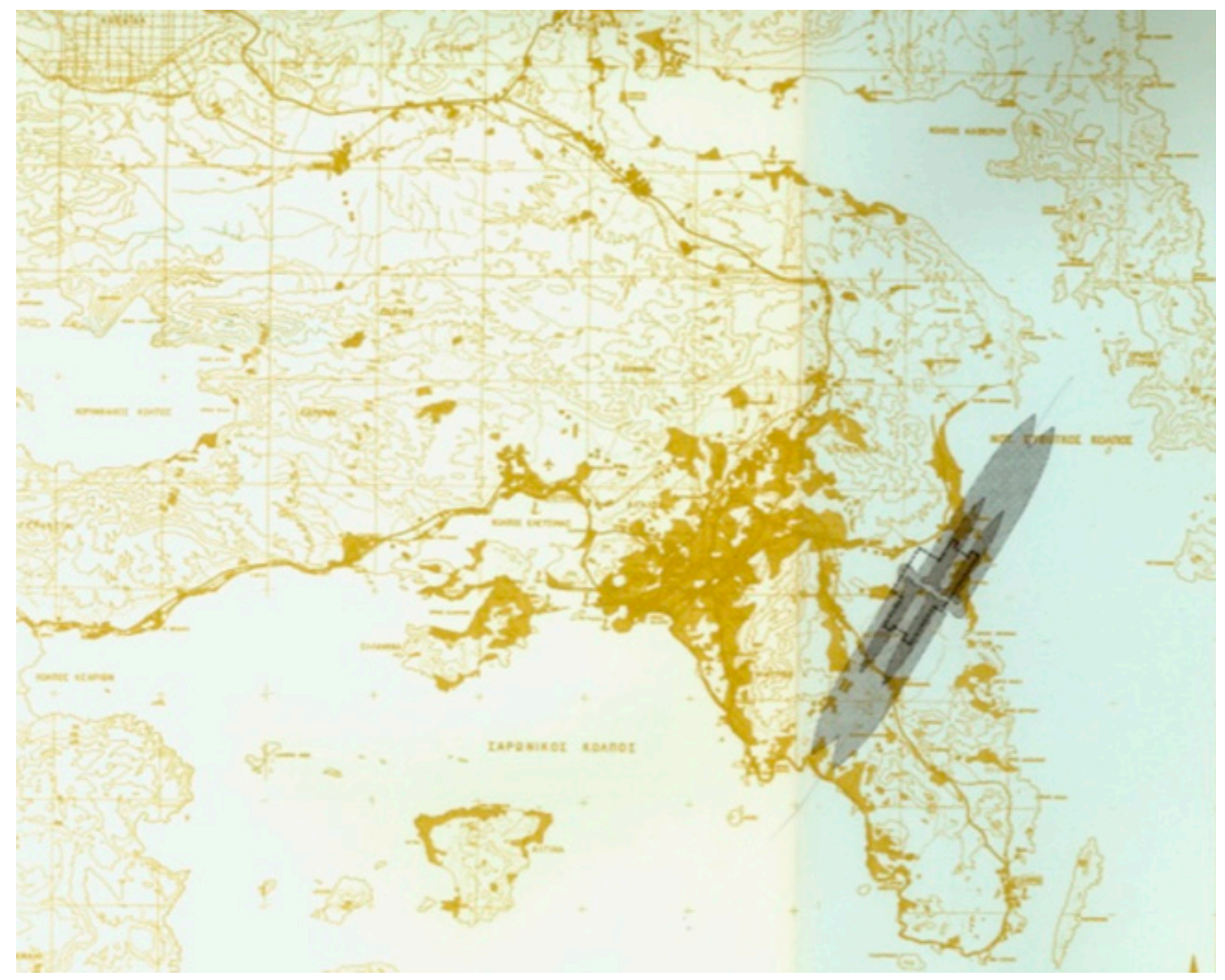

Figure 5. The estimated 'noise area' caused by the new airport (Source: redrawn by an original map provided by Technical Construction Chamber of Greece).

\subsection{From Town Planning to Regional Planning: The 21st Century}

The first attempt to change the traditional approach of urban planning into territorial planning and to introduce a wider strategic perspective was proposed by the Ministry of Planning, Environment, and Public Works in 1994, with the ATTIKI SOS Plan [31]. It was a non-regulatory action plan, which made extensive reference to long-term sustainability in policy strategies. Ambitious goals were set to promote the sustainable development of Athens and its entire metropolitan area.

At the beginning of the new century, the organization of the Olympic Games changed the perspective of Athens's development stressing the need for strategic planning, which acquired important operational tools. In this regard, the Ministry of Planning, Environment and Public Works, given the new drivers and trends of urban development in the region, took the initiative to launch a review of the Regulatory Plan (2000). The new Athens Regulatory Plan introduced significant elements of strategic planning which involved central, regional, and local administrations. It also promoted a competition (2003) to develop the operational specification of the regulatory plan, aimed at speeding up implementation procedures and encouraging coordination among the different programs and projects. A further initiative in the direction of a strategic approach to planning the Athens Metropolitan Area was directly promoted by the Planning Ministry, which instructed a group of experts to draft a strategic plan, called the "Strategic spatial development framework for Athens-Attica" [61].

During the drafting phase, particular attention was paid to the European role that the Athens-Attica region could play at an international level, given its location at a nodal point between Southeast Europe and the Arab world. The proposed strategy was diversified in the medium term (2006), and in the long term (2015), defining proposals for the Strategic Regional Planning Framework and 
Sustainable Development of Attica 2015, anticipated for a Strategic Action Program and the Impact Assessment of the Strategic Context on the Athens Regulatory Plan. In particular, the strategy aimed at strengthening Attica's international relevance in specific economic sectors in the short term, promoting a more competitive policy for the expansion of Athens-Attica's international role in the long term. The development of possible scenarios was based on the following strategic objectives: (i) economic development and competitiveness into the national-international-European network; (ii) sustainable urban development, improving life quality and promoting environmental protection of relict natural sites; (iii) stable population in the region, promoting social development and cohesion; (iv) suitable strategic planning and balanced urban development at all levels of geographical units, redesigning administrative structures and metropolitan governance. The rationale under such objectives was that Attica should act as a development pole: the whole of Greece should benefit from the presence of an international metropolitan area in turn reducing Athens' weight. The development of a metropolitan area aimed at favouring the attraction of cultural events, commercial transit, and service centres for macro-regional enterprises.

Even with these premises, the Athens Regulatory Plan was subjected to substantial changes without following the usual administrative process because of the urgency, the exceptionally, and the great importance of the 2004 Olympic Games, in terms of public interest. Such an exceptional procedure was also applied to lower administrative levels. In each hosting location, the Olympic infrastructure, the Ministry of Planning, and the Ministry of Culture in consultation with the Athens Regulatory Plan and the local administrations formed an Integrated Plan, which had to be approved by the presidential decree. The power of local governments was, in fact, reduced, limiting their intervention in the planning process to a purely advisory role. Exceptional procedures were also extended to land acquisition and expropriation, as well as how to use public assets and coastal areas. From this point of view, the planning process implemented for the Olympic Games in Athens lacked one of the key features of strategic and sustainable planning: the intergovernmental consensus and consultation with local instances [35]. The main implementing tools were the Special Integrated Plans, with regard to physical projects and a series of cooperation pacts (Program Agreements, Protocols of Understanding and Program Contracts) between the involved Ministries, local administrations, public bodies, and private organizations.

Assessments of the socioeconomic impact of the Olympic Games on the Athens' metropolitan region largely remained on paper. In fact, the analysis of the benefits of the Olympic Games was based on the basic assumption of impulses that the economic system (tourism, the balance of payments, investment, consumption, and employment) may receive from the new infrastructural system. The immediate result of the strategies and projects promoted for the Olympic Games has been the transformation of the entire Attica region and, above all, the metropolitan area of Athens into a colossal shipyard. Despite the ambitious goal of promoting strategic and sustainable growth, the Olympic Games in 2004 have left a relevant public debt for Greece and important projects that were managed by large private enterprises. The "Mall Athens" shopping centre, the new "Neratziotissa" station connecting line 1 of the metro and the suburban train network, the huge ping-pong building next to Omorfokklisia, the Press Office Centre at Kifissias Boulevard becoming another mall owned by the same entrepreneur were only examples of the inherent conversion of old structures in new activities. Other initiatives, such as the Agios Kosmas beach converted into a giant marina for private yachts with its services, the beach of the Faliro Delta and the "Olympic plants" went in the same direction. The cases of Skinias, the port of Faliro, and the "International Centre" of the Olympic Village were also well-known examples of structures remained unused after the Olympics, suggesting the weakness of a top-down strategy justified by emergency procedures.

Territorial planning and the foreseeability of a country's sustainable development led to approaches emphasizing the need to further integrate the regional area with Athens. As an example, the Regional Development Plan of the Region (REC) 2000-2006 (Law 2742/99, the Framework for Territorial Planning and Sustainable Development) extended far beyond the city of Athens, covering the entire Attica 
region, and considering the area affected by commuting between places of residence and work, to underline interdependence with the capital [62]. In this context, specific importance was given to the Athens-Lamia development axis, which was entrusted with the task of improving the prospects for the development of urban centres in the region. The plan assumed that a polycentric structure will strengthen the regional and interregional expansion of urban centres, leading to new development dynamics, and creating influences beyond the administrative boundaries of the centres involved. The region was therefore divided into homogeneous zones in terms of geography, type, and mode of development. These areas included six land classes as follows: (A) Building Areas, from Athens up to the mountains, a totally urbanized zone; (B) Plain areas of Thriasio and Messoghia, showing a tendency to urbanization in the form of residential development, development of productive activities and social development (education, recreation, sport); (C) a Coastal Zone encompassing the Saronic Gulf and Evia, characterized by the development of residential areas, tourism, and recreation; (D) Hill areas with sporadic urban development; (E) Mountainous districts with natural areas and forests with weak urban pressure concentrated in traditional rural villages; and (F) Argosaronic islands.

The spatial organization of Attica was the basis of the Strategic Plan. Indeed, the various centres acted as clusters of economic activities, providing services to the population, and poles of the social structure, giving identity to the metropolitan region. Individual spatial units were considered as project modules or as spatial elements of metropolitan governance, through which the spatial regions and the competent authorities at different levels (e.g., district, county, local section) should be connected. In this sense, their design was of great importance. Particular emphasis was given to the territorial dimension of Attica's centres in order to create a network of connections to support the strategic role and territorial development of the Greek capital.

The last effort to streamline and decentralize the complex system of sub-national authorities was the 2011 Kallikratis reform that reduced the number of Greek municipalities from 1034 to 325 . However, fiscal resource allocation across and within levels of government was not truly reformed. Still, public transportation improvement was seen as a pressing challenge. In 2011, the Greek government merged several operating companies streamlining transportation governance in the Athens metropolitan area under a big company named OASA. Being part of the Ministry of Infrastructure, Transport, and Networks, OASA early manifested a lack of coordination with the local or regional authorities on transport planning.

\section{Current Challenges and Future Directions}

The metropolitan area of Athens extends nearly $3000 \mathrm{~km}^{2}$ and hosts 3.7 million resident inhabitants. While being already a capital city, Athens underwent a period of rapid development and modernization after the Second World War. During the last decades, the (mostly unplanned) urban growth and massive housing construction quickly transformed Athens and the surrounding region, imposing a modern (but at times haphazard) character [63]. The de-concentration of services, as envisaged in the 1985 plan for the lightening of the centre, coupled with the "growth of the land market" as hypothesized with a planned expansion of cropland in the peri-urban area, led to the isolation of the main services [64]. Furthermore, the disproportional urban expansion and the realization of the great works for the Olympics have created a favourable ground for economic recession. New infrastructure, including public transportation, were developed, but growth was mostly chaotic, with proliferation of multi-story residential buildings [65]. This building typology allowed mixed uses (residential and commercial) as well as a sort of vertical stratification among social classes and ethnic identities. In addition, recent urban sprawl caused low living density. Buildings were constituted by a limited number of floors, being mostly detached. More parking and roads were functional for the use of the car, which causes car-dependency, congestion, air pollution, and the degradation of the environment. The result was that fringe land was urbanized at a higher rate than the population growth [66]. Consequently, non-conforming soils were often used with incompatible uses. 
In the absence of integrated planning (with the only exception of the Dioxiadis plan of 1985) the pressure on the natural environment grew exponentially. Massive construction and a rapidly growing road system caused a loss of urban and peri-urban green areas and most of the Attica water network (including its two rivers) was covered. This has contributed to increasing temperatures, heat waves, and frequency of flush-floods $[67,68]$. Furthermore, the metropolitan area of Athens proved to be sensitive to deforestation because of different drivers, including land take, urbanization of peripheries, and wildfires [22]. In the built-up areas, an insufficient climate protection of existing buildings was observed, and public works or new building construction disregarded local climate conditions. In addition, the lack of updated legislation on energy and environmental protection for buildings and other urban infrastructure, have contributed to an increase of the urban heat island effect, coupled with social and economic decline of the city centre. Athens has also experienced natural disasters and 'external shocks' other than those related to climate change. Among these, the City of Athens listed earthquakes, civil unrest demonstrations, and cybercrime [35]. All these events contributed to increasing the weaknesses of the city and the long-term stresses underlying them (depressed macroeconomic conditions, aging infrastructure, migration, mistrust).

Despite efforts to guide urban growth, a series of structural challenges have remained: (i) a gap between planning and implementation; (ii) an even stronger gap between spatial planning and socioeconomic planning; (iii) the incomplete development of basic land management tools; (iv) the lack of participatory planning. In order to face these problems and to foster resilience in Athens, metropolitan governance reforms, and a carefully designed financial scheme must be implemented. Stakeholder mobilization has to focus on a shared set of policy priorities for a more "Open, Green, Proactive and Vibrant City", as proposed in the Athens Resilience Strategy for 2030 [35]. The main goals of such a strategy are to (i) maximize the economic dynamics of the Athenian neighbourhood, (ii) promote a data-driven and inclusive city, (iii) increase nature in the city, and (iv) enhance social cohesion. According to these ambitious aims, the strategy proposes a list of actions to achieve effective and efficient governance through the involvement of its residents along with the different phases of decision making, by fostering data-driven policymaking and accountability, promoting well-being, creativity, and entrepreneurship [69].

Major efforts in Resilience Strategy for 2030 was given to the actions that may support climate change adaptation and increase of environmental protection, recognizing the leading role of Nature-Based Solutions in increasing the environmental quality and sustainability in urban and peri-urban contexts [70-73]. With regards to urban forest management [74], guidelines were more recently provided for managing environmental resources and increasing its protection, e.g., from wildfires [75] in Attica (Figure 6). This map well depicts the spatial integration between economic nodes and social functions in the region and the environmental heritage surrounding urban fabrics. Specific linkages were illustrated between the biggest node (downtown Athens) and other three sub-centres (Piraeus harbour, South of Athens, Thriasio industrial settlement, West of Athens, and Messoghia district including the International Airport, East of Athens). These interconnections underline the most relevant development axes in Attica. Less intense developmental axes were also envisaged in other two socioeconomic nodes (Salamina, south-west of Piraeus and Lavrio, South-east of Messoghia). Finally, the Argosaronic islands (Aegina, Poros, Idra, Spetses), truly south of Athens but administratively belonging to Attica, were also designed as 'minor' socioeconomic nodes. Environmental heritage is conserved in natural (rural) places (more or less) far from these development axes, as clearly demonstrated in Figure 6. 


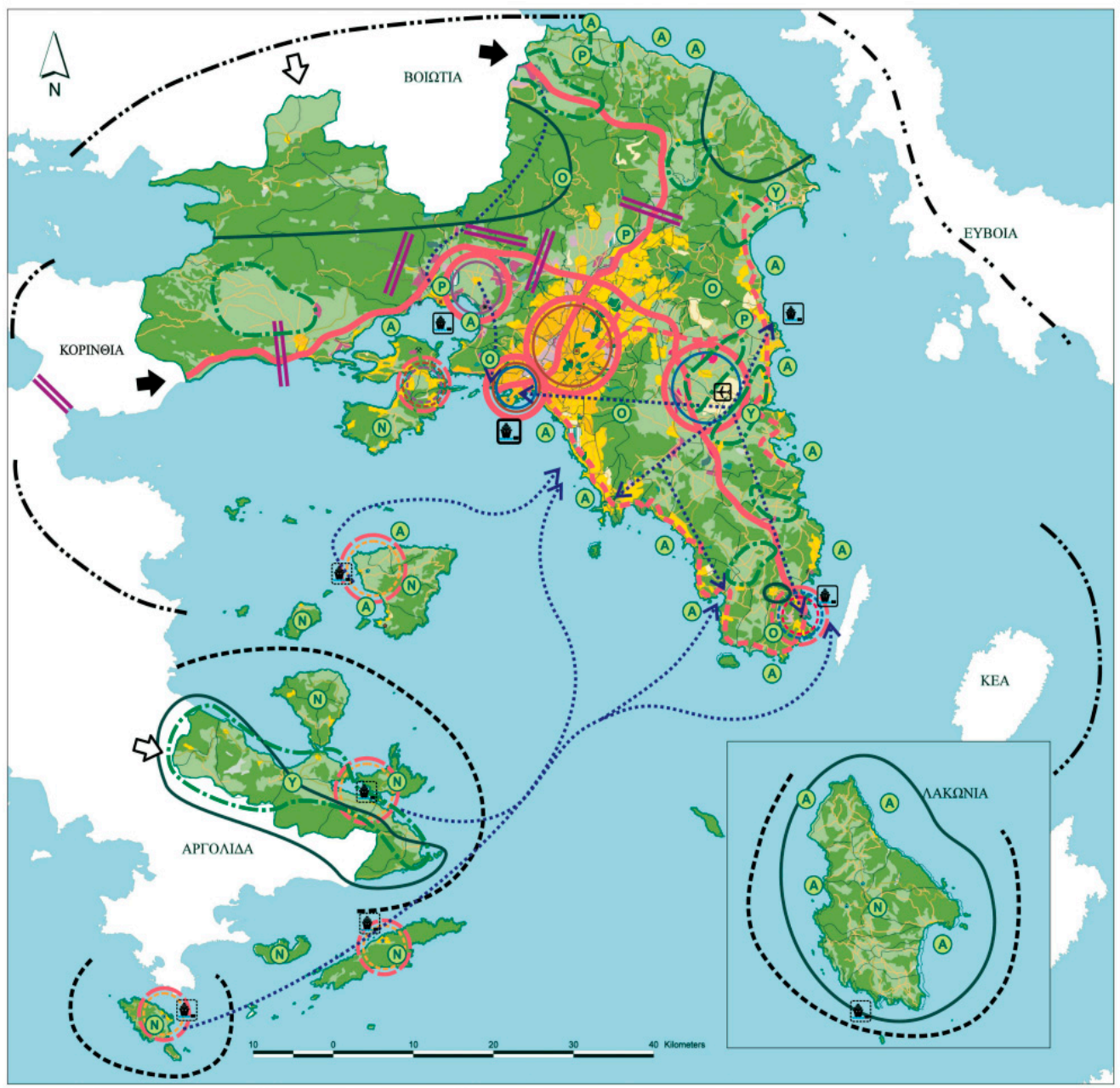

Figure 6. A symbolic map illustrating a possible spatial integration of urban nodes and services (ports, airport) with the environmental system in Attica (redrawn from http://courses.arch.ntua.gr/129909.html).

More specifically, the natural/rural part of the study region has been divided into districts that determine restrictions in relation to land use and new constructions, aimed at halting the uncontrolled spread of urbanization, removing incompatibilities, providing recreational facilities, and other activities for the conservation and enhancement of greenery. Protection of agricultural land, archaeological sites, and green areas to guarantee development sites for the maintenance of ecological balance has been proposed. Some rivers of Attica have been included in a list of protected nature conservation elements with the intention of protecting and managing these land resources as an integral part of Attica's landscape. Plans and programs have been set up to create parks and public greenery, by implementing a complex and comprehensive environmental system for the region and integrating urban areas with green corridors and environmental impact studies for the creation of new archaeological sites.

In this context, to increase the resilience of the entire system, agricultural land requires a particular attention [15]. For instance, effective protection of agricultural areas, and especially crop mosaics with relict woodlots, is particularly needed $[76,77]$. The application of sustainable agricultural measures is also recommended, including greening measures defined by the new Common Agricultural Policy [78]. Further, the establishment of improved ecological networks constituted by tree lines, bushes, or wetlands, may help to provide multiple ecosystem services [22,72,79].

With the current crisis, given the socio-political conditions of Greece, there is no prospect of a new master plan for Athens. However, recently, as a part of the Athens Resilience Strategy [35], the Athens Climate Change Adaptation and Mitigation Action Plans were proposed. They tried to answer the question of increasing city resilience and to provide guidelines for more sustainable management of 
the built and natural landscape. They outline concrete steps for improving the urban quality of life in the face of increasing temperatures, flash floods, and poor air quality. The city of Athens proposes that climate change resilience should be the backbone of all city's policies and that it should become embedded in the administrations' economic logic.

\section{Concluding Remarks}

During the last decades, town planning in Athens has proposed ambitious development objectives, which seemed to have not been achieved, at least in part. Policy choices were mainly aimed at stabilizing Athens' economy, improving the competitiveness of the metropolitan area through a new relationship between the public economy and private enterprise. The main tools to achieve these goals were private and public investments. All were supported by infrastructure development to improve city functionality, quality of life, and business competitiveness. Based on the analysis of past planning history, Athens comes up as a contradictory case and probably an unsuccessful opportunity to a significant propensity to innovation manifested in the formulation of planning strategies, followed the decision-making phase in favour of a drastic simplification and re-centralization of the decision-making process, involving all relevant institutional and local actors. In this framework, environmental protection was seen as a policy option less clearly linked with economic development. Natural places were mostly protected (or left untouched from land speculation) because of their remoteness and difficult accessibility (e.g., mountain areas). Rural places at the fringe of Athens were instead destroyed, fragmented, or heavily damaged, irrespective of the high landscape quality and considerable biodiversity stock, simply because of their proximity with developmental axes.

After decades of contrasting plans, moving progressively toward a less rhetoric and more factual strategy of landscape protection, The Strategic Plan today tends to shape itself as the blueprint for the integration of economic, social and environmental policies, which identifies critical relationships between policies and sectorial developmental projects. It seeks to coordinate them effectively, promoting interactive co-planning procedures, and expressing sophisticated technical expertise. Furthermore, the Athens Resilience Strategy for 2030 proposes a list of actions to improve the well-being of citizens and to foster sustainability at the urban and territorial levels. In this sense, a major role was given to the enhancement of the environmental quality of the metropolitan area and to the involvement of inhabitants in the various phases of decision making.

Although many guidelines have been produced, as shown by our study, the intrinsic fragmentation of local plans and the substantial weakness of regional strategies may leave all these proposals on the paper. A particularly important issue is that economic development and environmental protection policies were spatially delinked, not only in past planning experiences, —at least in some ways-also in current strategies, with a partial connection with social cohesion issues. In other words, economic development and environmental protection were (and, in some aspects) still are seen as spatially distinct priorities. This means that ecological measures were considered particularly appropriate for remote locations and leaving (more accessible) natural places surrounding Athens to the negative (direct or indirect) impact of infrastructural development. In these regards, the lack of an institutional framework regulating metropolitan growth is expected to cause an even increasing pressure on the natural environment. In this regard, a possible solution for Athens, as well as for other city contexts in Southern Europe with similar urban paths, is a master plan which harmonizes large-scale interventions at regional level and small-scale projects. Certainly, the large scale is considered the most pertinent and consistent to promote inclusive approaches and especially to manage dispersion, segregation, and settling phenomena. However, the respect of local peculiarities, cultures and identities should be assured, improving social cohesion and promoting, in this way, a multi-scale sustainability and resilience. 
Author Contributions: Conceptualization, A.T. and S.S.N.; methodology, A.G.M.; validation, A.T. and A.G.M.; formal analysis, A.T.; investigation, S.S.N.; resources, S.S.N.; data curation, L.S.; writing—original draft preparation, A.T. and L.S.; writing-review and editing, S.S.N. and G.Q.; visualization, A.G.M.; supervision, G.Q.; project administration, A.T.; funding acquisition, S.S.N. All authors have read and agreed to the published version of the manuscript.

Funding: This research received no external funding.

Conflicts of Interest: The authors declare no conflict of interest.

\section{References}

1. Brabec, E.; Schulte, S.; Richards, P.L. Impervious surfaces and water quality: A review of current literature and its implications for watershed planning. J. Plan. Lit. 2002. [CrossRef]

2. Todeschini, S.; Papiri, S.; Ciaponi, C. Placement Strategies and Cumulative Effects of Wet-weather Control Practices for Intermunicipal Sewerage Systems. Water Resour. Manag. 2018. [CrossRef]

3. Carranza, M.L.; Drius, M.; Marzialetti, F.; Malavasi, M.; de Francesco, M.C.; Acosta, A.T.R.; Stanisci, A. Urban expansion depletes cultural ecosystem services: An insight into a Mediterranean coastline. Rend. Lincei 2020. [CrossRef]

4. Zhang, T.; Sun, B.; Li, W. The economic performance of urban structure: From the perspective of Polycentricity and Monocentricity. Cities 2017. [CrossRef]

5. Ahern, J. Urban landscape sustainability and resilience: The promise and challenges of integrating ecology with urban planning and design. Landsc. Ecol. 2013, 28, 1203-1212. [CrossRef]

6. Bibri, S.E.; Krogstie, J.; Kärrholm, M. Compact city planning and development: Emerging practices and strategies for achieving the goals of sustainability. Dev. Built Environ. 2020. [CrossRef]

7. Lee, S.; Lee, B. The influence of urban form on GHG emissions in the U.S. household sector. Energy Policy 2014. [CrossRef]

8. Wang, M.; Madden, M.; Liu, X. Exploring the Relationship between Urban Forms and $\mathrm{CO}_{2}$ Emissions in 104 Chinese Cities. J. Urban Plan. Dev. 2017. [CrossRef]

9. Bardhan, R.; Kurisu, K.; Hanaki, K. Does compact urban forms relate to good quality of life in high density cities of India? Case of Kolkata. Cities 2015. [CrossRef]

10. Salvati, L.; Ferrara, A.; Chelli, F. Long-term growth and metropolitan spatial structures: An analysis of factors influencing urban patch size under different economic cycles. Geogr. Tidsskr. Danish J. Geogr. 2018. [CrossRef]

11. Salvati, L.; Quatrini, V.; Barbati, A.; Tomao, A.; Mavrakis, A.; Serra, P.; Sabbi, A.; Merlini, P.; Corona, P. Soil occupation efficiency and landscape conservation in four Mediterranean urban regions. Urban For. Urban Green. 2016. [CrossRef]

12. Zambon, I.; Benedetti, A.; Ferrara, C.; Salvati, L. Soil Matters? A Multivariate Analysis of Socioeconomic Constraints to Urban Expansion in Mediterranean Europe. Ecol. Econ. 2018. [CrossRef]

13. Colantoni, A.; Mavrakis, A.; Sorgi, T.; Salvati, L. Towards a 'polycentric' landscape? Reconnecting fragments into an integrated network of coastal forests in Rome. Rend. Lincei 2015. [CrossRef]

14. Delfanti, L.; Colantoni, A.; Recanatesi, F.; Bencardino, M.; Sateriano, A.; Zambon, I.; Salvati, L. Solar plants, environmental degradation and local socioeconomic contexts: A case study in a Mediterranean country. Environ. Impact Assess. Rev. 2016. [CrossRef]

15. Smiraglia, D.; Ceccarelli, T.; Bajocco, S.; Salvati, L.; Perini, L. Linking trajectories of land change, land degradation processes and ecosystem services. Environ. Res. 2016. [CrossRef] [PubMed]

16. Salvati, L.; Zitti, M. The environmental "risky" region: Identifying land degradation processes through integration of socio-economic and ecological indicators in a multivariate regionalization model. Environ. Manag. 2009. [CrossRef] [PubMed]

17. Di Feliciantonio, C.; Salvati, L.; Sarantakou, E.; Rontos, K. Class diversification, economic growth and urban sprawl: Evidences from a pre-crisis European city. Qual. Quant. 2018. [CrossRef]

18. Salvati, L.; Carlucci, M.; Grigoriadis, E.; Chelli, F.M. Uneven dispersion or adaptive polycentrism? Urban expansion, population dynamics and employment growth in an 'ordinary' city. Rev. Reg. Res. 2018. [CrossRef]

19. Zhao, P.; Luë, B.; de Roo, G. Urban expansion and transportation: The impact of urban form on commuting patterns on the city fringe of Beijing. Environ. Plan. A 2010. [CrossRef] 
20. Li, F.; Zhou, T. Effects of urban form on air quality in China: An analysis based on the spatial autoregressive model. Cities 2019. [CrossRef]

21. Tao, Y.; Zhang, Z.; Ou, W.; Guo, J.; Pueppke, S.G. How does urban form influence PM2.5 concentrations: Insights from 350 different-sized cities in the rapidly urbanizing Yangtze River Delta region of China, 1998-2015. Cities 2020. [CrossRef]

22. Tomao, A.; Quatrini, V.; Corona, P.; Ferrara, A.; Lafortezza, R.; Salvati, L. Resilient landscapes in Mediterranean urban areas: Understanding factors influencing forest trends. Environ. Res. 2017. [CrossRef] [PubMed]

23. Di Feliciantonio, C.; Salvati, L. "Southern" Alternatives of Urban Diffusion: Investigating Settlement Characteristics and Socio-Economic Patterns in Three Mediterranean Regions. Tijdschr. Econ. Soc. Geogr. 2015. [CrossRef]

24. Salvati, L. Towards a Polycentric Region? The Socio-economic Trajectory of Rome, an "Eternally Mediterranean" City. Tijdschr. Econ. Soc. Geogr. 2014. [CrossRef]

25. Chorianopoulos, I.; Pagonis, T.; Koukoulas, S.; Drymoniti, S. Planning, competitiveness and sprawl in the Mediterranean city: The case of Athens. Cities 2010. [CrossRef]

26. Carlucci, M.; Chelli, F.M.; Salvati, L. Toward a new cycle: Short-term population dynamics, gentrification, and re-urbanization of Milan (Italy). Sustainability 2018, 10, 3014. [CrossRef]

27. Ciommi, M.; Gentili, A.; Ermini, B.; Gigliarano, C.; Chelli, F.M.; Gallegati, M. Have Your Cake and Eat it Too: The Well-Being of the Italians (1861-2011). Soc. Indic. Res. 2017. [CrossRef]

28. Salvati, L.; Ciommi, M.T.; Serra, P.; Chelli, F.M. Exploring the spatial structure of housing prices under economic expansion and stagnation: The role of socio-demographic factors in metropolitan Rome, Italy. Land Use Policy 2019. [CrossRef]

29. Chorianopoulos, I.; Tsilimigkas, G.; Koukoulas, S.; Balatsos, T. The shift to competitiveness and a new phase of sprawl in the Mediterranean city: Enterprises guiding growth in Messoghia-Athens. Cities 2014. [CrossRef]

30. Kaika, M. The economic crisis seen from the everyday: Europe's nouveau poor and the global affective implications of a "local" debt crisis. City 2012. [CrossRef]

31. Pagonis, A. The Evolution of Metropolitan Planning Policy in Athens over the Last Three Decades: Linking Shifts in the Planning Discourse with Institutional Changes and Spatial Transformation. 2013. Available online: http://courses.arch.ntua.gr/fsr/144683/Athens\%20Metropolitan\%20Planning\%20Policy.pdf (accessed on 11 November 2020).

32. Souliotis, N. Cultural economy, sovereign debt crisis and the importance of local contexts: The case of Athens. Cities 2013. [CrossRef]

33. De Rosa, S.; Salvati, L. Beyond a "side street story"? Naples from spontaneous centrality to entropic polycentricism, towards a "crisis city". Cities 2016. [CrossRef]

34. Salvati, L. The Dark Side of the Crisis: Disparities in per Capita income (2000-12) and the Urban-Rural Gradient in Greece. Tijdschr. Econ. Soc. Geogr. 2016. [CrossRef]

35. City of Athens Redefining the City: Athens Resilience Strategy for 2030. 2017. Available online: https://resilientathens.files.wordpress.com/2017/07/athens_resilience_strategy_-_reduced_pdf-compressed.pdf (accessed on 18 September 2020).

36. Economou, D. The planning system and rural land use control in Greece: A European perspective. Eur. Plan. Stud. 1997. [CrossRef]

37. Leontidou, L. Alternatives to modernism in (southern) urban theory: Exploring in-between spaces. Int. J. Urban Reg. Res. 1996. [CrossRef]

38. Petsimeris, P.; Tsoulouvis, L. Current trends and prospects of future change in the Greek urban system. Riv. Geogr. Ital. 1997, 104, 421-443.

39. Kourliouros, E. Planning industrial location in Greater Athens: The interaction between deindustrialization and anti-industrialism during the 1980s. Eur. Plan. Stud. 1997. [CrossRef]

40. Kourliouros, E. Reflections on the economic-noneconomic debate: A radical geographical perspective from the European South. Antipode 2003. [CrossRef]

41. Beriatos, E.; Gospodini, A. "Glocalising" urban landscapes: Athens and the 2004 olympics. Cities 2004. [CrossRef]

42. Salvati, L.; Sateriano, A.; Grigoriadis, E. Crisis and the city: Profiling urban growth under economic expansion and stagnation. Lett. Spat. Resour. Sci. 2016. [CrossRef] 
43. Gospodini, A. Urban design, urban space morphology, urban tourism: An emerging new paradigm concerning their relationship. Eur. Plan. Stud. 2001. [CrossRef]

44. Gospodini, A. Portraying, classifying and understanding the emerging landscapes in the post-industrial city. Cities 2006. [CrossRef]

45. Gospodini, A. Post-industrial trajectories of Mediterranean European Cities: The case of post-olympics Athens. Urban Stud. 2009. [CrossRef]

46. Chorianopoulos, I. North-south local authority and governance differences in EU networks. Eur. Plan. Stud. 2003. [CrossRef]

47. Maloutas, T. Promoting social sustainability The case of Athens. City 2003. [CrossRef]

48. Maloutas, T. Segregation, social polarization and immigration in Athens during the 1990s: Theoretical expectations and contextual difference. Int. J. Urban Reg. Res. 2007. [CrossRef]

49. Giannakourou, G. Transforming spatial planning policy in Mediterranean countries: Europeanization and domestic change. Eur. Plan. Stud. 2005. [CrossRef]

50. Arapoglou, V.P.; Sayas, J. New facets of urban segregation in Southern Europe: Gender, migration and social class change in Athens. Eur. Urban Reg. Stud. 2009, 16, 345-362. [CrossRef]

51. Kandylis, G.; Maloutas, T.; Sayas, J. Immigration, inequality and diversity: Socio-ethnic hierarchy and spatial organization in Athens, Greece. Eur. Urban Reg. Stud. 2012. [CrossRef]

52. Panori, A.; Psycharis, Y.; Ballas, D. Spatial segregation and migration in the city of Athens: Investigating the evolution of urban socio-spatial immigrant structures. Popul. Space Place 2018. [CrossRef]

53. Vaiou, D. Milestones in the urban history of Athens. Treballs la Soc. Catalana Geogr. 2002, 53-54, $209-226$.

54. Marmaras, E. The Greek System of Home Ownership and the Post-2008 Crisis in Athens. Reg. Dev. 2014, 39, 167-182.

55. Vaiou, D. Facets of spatial development and planning in Greece. Eur. Plan. Stud. 1997, 5, 431-433. [CrossRef]

56. Delladetsima, P.M. The emerging property development pattern in Greece and its impact on spatial development. Eur. Urban Reg. Stud. 2006. [CrossRef]

57. Kazemzadeh-Zow, A.; Zanganeh Shahraki, S.; Salvati, L.; Samani, N.N. A spatial zoning approach to calibrate and validate urban growth models. Int. J. Geogr. Inf. Sci. 2017. [CrossRef]

58. Katsibokis, G. Ktiriothiki: The architectural heritage of Athens, 1830-1950. J. Mod. Greek Stud. 2013. [CrossRef]

59. Skayannis, P. The (master) plans of athens and the challenges of its re-planning in the context of crisis. Archnet-IJAR 2013. [CrossRef]

60. Roubien, D. Creating Modern Athens: A Capital between East and West; Taylor \& Francis: Abingdon, UK, 2017; ISBN 9781351966177.

61. Serraos, K.; Gianniris, E.; Zifou, M. The Greek spatial and urban planning system in the European context. In Complessitá e Sostenibilitá. Prospettive per i Territori Europei: Strategie di Plannificazione in Dieci Paesi; Poli. Design: Milano, Italy, 2005; Available online: https://www.researchgate.net/publication/292074559 (accessed on 11 November 2020).

62. Ciommi, M.; Chelli, F.M.; Salvati, L. Integrating parametric and non-parametric multivariate analysis of urban growth and commuting patterns in a European metropolitan area. Qual. Quant. 2019. [CrossRef]

63. Petsimeris, P. Population deconcentration in Italy, Spain and Greece: A first comparison. Ekistics 2002, 69, 163-172.

64. Hadjimichalis, C. From Streets and Squares to Radical Political Emancipation? Resistance Lessons from Athens during the Crisis. Hum. Geogr. 2013. [CrossRef]

65. Marmaras, E. The privately-built multi-storey apartment building: The case of inter-war Athens. Plan. Perspect. 1989. [CrossRef]

66. Ciommi, M.; Chelli, F.M.; Carlucci, M.; Salvati, L. Urban growth and demographic dynamics in southern Europe: Toward a new statistical approach to regional science. Sustainability 2018, 10, 2765. [CrossRef]

67. Salvati, L.; Perini, L.; Sabbi, A.; Bajocco, S. Climate Aridity and Land Use Changes: A Regional-Scale Analysis. Geogr. Res. 2012. [CrossRef]

68. Founda, D.; Santamouris, M. Synergies between Urban Heat Island and Heat Waves in Athens (Greece), during an extremely hot summer (2012). Sci. Rep. 2017. [CrossRef] [PubMed]

69. Coccossis, H.; Economou, D.; Petrakos, G. The ESDP relevance to a distant partner: Greece. Eur. Plan. Stud. 2005. [CrossRef] 
70. Lafortezza, R.; Chen, J. The provision of ecosystem services in response to global change: Evidences and applications. Environ. Res. 2016. [CrossRef] [PubMed]

71. Maes, J.; Jacobs, S. Nature-Based Solutions for Europe's Sustainable Development. Conserv. Lett. 2017. [CrossRef]

72. Ferrari, B.; Quatrini, V.; Barbati, A.; Corona, P.; Masini, E.; Russo, D. Conservation and enhancement of the green infrastructure as a nature-based solution for Rome's sustainable development. Urban Ecosyst. 2019. [CrossRef]

73. Tzoulas, K.; Galan, J.; Venn, S.; Dennis, M.; Pedroli, B.; Mishra, H.; Haase, D.; Pauleit, S.; Niemelä, J.; James, P. A conceptual model of the social-ecological system of nature-based solutions in urban environments. Ambio 2020. [CrossRef]

74. Bajocco, S.; De Angelis, A.; Salvati, L. A satellite-based green index as a proxy for vegetation cover quality in a Mediterranean region. Ecol. Indic. 2012. [CrossRef]

75. Bajocco, S.; Salvati, L.; Ricotta, C. Land degradation versus fire: A spiral process? Prog. Phys. Geogr. 2011, 35, 3-18. [CrossRef]

76. Recanatesi, F.; Clemente, M.; Grigoriadis, E.; Ranalli, F.; Zitti, M.; Salvati, L. A fifty-year sustainability assessment of Italian agro-forest districts. Sustainability 2016, 8, 32. [CrossRef]

77. Gasparella, L.; Tomao, A.; Agrimi, M.; Corona, P.; Portoghesi, L.; Barbati, A. Italian stone pine forests under Rome's siege: Learning from the past to protect their future. Landsc. Res. 2017. [CrossRef]

78. Swinnen, J.F.M. The Political Economy of the 2014-2020 Common Agricultural Policy: Introduction and Key Conclusions. In The Political Economy of the 2014-2020 Common Agricultural Policy: An Imperfect Storm; Rowman \& Littlefield: Lanham, MD, USA, 2015.

79. Papangelis, G.; Tombrou, M.; Dandou, A.; Kontos, T. An urban "green planning" approach utilizing the Weather Research and Forecasting (WRF) modeling system. A case study of Athens, Greece. Landsc. Urban Plan. 2012. [CrossRef]

Publisher's Note: MDPI stays neutral with regard to jurisdictional claims in published maps and institutional affiliations.

(C) 2020 by the authors. Licensee MDPI, Basel, Switzerland. This article is an open access article distributed under the terms and conditions of the Creative Commons Attribution (CC BY) license (http://creativecommons.org/licenses/by/4.0/). 